\title{
Strategy discussion on college innovation and entrepreneurship education talent cultivation system construction
}

\author{
Xilan Wu \\ Jiangxi Science and Technology Normal University, Nanchang, 330013, China
}

\begin{abstract}
Keywords: College innovation and entrepreneurship education, Talent cultivation system, Issues and strategies.
\end{abstract}

\begin{abstract}
China started implementing national innovation-driven development strategy which has huge impact on colleges and universities and they have also started changing traditional concept and cultivating innovative talents to satisfy social demands. College innovation and entrepreneurship education talent cultivation system is more and more important especially for application oriented colleges. Constructing college innovation and entrepreneurship education talent cultivation system can help deliver talents for China and promoting economic transition and development.
\end{abstract}

\section{Introduction}

This article mainly discusses the importance of college innovation and entrepreneurship education, issues and countermeasures during the process of implementing, and then makes a comprehensive illustration for the future development direction. During the process, we must clarify Chinese existing policies and make sure the macro direction cannot go wrong so as to guarantee the correctness and comprehensiveness of constructing talent cultivation system. To cope with the emerging challenges in modern time, we must give a scientific positioning of college innovation and entrepreneurship education to strengthen college students' quality and improve their ability to create better future.

\section{Importance of college innovation and entrepreneurship education talent cultivation system construction}

Chinese college innovation and entrepreneurship education talent cultivation system is to promote students' comprehensive development and employment through innovation education and penetrate innovation and entrepreneurship awareness throughout students' daily life by cultivating students' innovation awareness so as to form independent innovation concept and create talents comprehensively through establishing talent cultivation system and make students fully dig and develop their advantages and find ways and means for startup. College's providing a platform for students can release students' burden and offer them related employment chances and lay foundations for them before stepping into the society. In nowadays society, there exist a lot of conditions such as disconnection between the society and school, students' failure to apply theoretical knowledge into practice. And college innovation and entrepreneurship education talent cultivation system construction can make up for the defects. Meanwhile, the entrepreneurship education cultivation is closely related with other subjects, to perfect integration between different subjects. It deserves further studies in the new field for further expansion. The coordination between different fields can expand the research range, which is of great significance although it is hard during the implementation process. 


\section{Issues existing in college innovation and entrepreneurship education talent cultivation system construction}

Chinese college innovation and entrepreneurship education started later than the foreign countries but with rapid development and obvious achieements. But there are huge issues in the development process facing a lot of challenges mainly including the insufficient professionalism, cohesion and not theoretical enough.

\section{College innovation and entrepreneurship education lack professionalism}

In Chinese colleges, innovation and entrepreneurship education has been carried out but professionalism is not enough which is reflected in specific development direction and courses. Professionalism refers to that college innovation and entrepreneurship education should own special subjects, expert type team and professional educational methods. But in Chinese college subjects and teaching resource setting, there are not enough facilities, and entrepreneurship education still require for independent subject support. Normally they are included in other subject without related expert team and well-developed teaching resources. Not equipped with software facilities, college innovation and entrepreneurship education faces some difficulties. There are not enough professional education methods and no professional college innovation and entrepreneurship education methods have been developed, which has brought about huge challenge and difficulties to the implementation.

\section{College innovation and entrepreneurship education lack consistency}

In Chinese colleges, college innovation and entrepreneurship education talent cultivation system construction is not perfect and not established well. Colleges are poor in education and teaching course system and overall planning with no strong consistency, and not suitable theoretical and practical implementation. After having the innovation and entrepreneurship education policies, Chinese colleges have not completely carried out the implementation and schools have low career planning for students and many of them are not clear about their developmental direction, poor in exterior practice. College innovation and entrepreneurship education is still limited within schools without establish consistent practice based with practical working units and enterprises outside school, which makes college theoretical knowledge study cannot develop and bring barriers for college innovation and entrepreneurship education talent cultivation construction.

\section{College innovation and entrepreneurship education is not theoretical enough}

Although many Chinese colleges have started implementing innovation and entrepreneurship education to increase students' awareness through different means and methods, there are not enough scientific guiding methods on how to specifically instruct students, what contents and how to teach students. College innovation and entrepreneurship education should not be only a practical work inside school but bringing huge impact on the social development and school development. It is closely related with various subjects. Bur based on existing research achievements, we have not constructed perfect system to support students' development which is mutual. We have never started from the subjectivity of students to research student's direction, rather than proposing a method. The theoretical construction is backward without strong theoretical support, thus there exist risks and confusions in our practice.

\section{Strategies of college innovation and entrepreneurship education system construction}

After proposing many issues above, we should propose related countermeasures to solve these problems and have a correct and scientific positioning on college innovation and entrepreneurship education, and establish theoretical knowledge system and frame so that our practice have basis for support. There are mainly several feasible strategies from several subjectivities of the country, society, school, and students themselves. 


\section{National aspect}

Chinese national development strategy is the major reason for college to carry out college innovation and entrepreneurship education system construction. College innovation and entrepreneurship education is related to the national economic development. Faced with serious domestic and foreign employment situation, the country has proposed the development strategy of expanding employment and promote employment through innovation to solve the problem. Innovative talent cultivation is to respond the strategy through changing traditional education positioning. The country should provide huge support in college innovation and entrepreneurship education process including manpower, material and financial support to cultivate students' entrepreneurship knowledge and skills. Meanwhile, the country should clarify the specific theories of college innovation and entrepreneurship education and make it more scientific to create good systematic theoretical knowledge for students, develop innovation and entrepreneurship education through learning domestic and foreign advanced experience for in-depth local research, create theories suitable for Chinese students' development by combining with practical condition of colleges and students' features, and meanwhile connect with knowledge in other fields to master macro developmental direction so as to provide good education from national level through integrating resources and coordinating various subjects to formulate Chinese innovation and entrepreneurship education development strategy.

\section{Social aspect}

Responsibility the society has undertaken is huge during the process of constructing talent cultivation system and to cultivate demanded talents is the obligation enterprises should bear in the society. Combine traditional "entrepreneur education" with "quality-oriented education" to form Chinese characteristics entrepreneurship education. Society should connect with schools when providing help so that both can be closely combined to provide real practical platform. During the process of constructing practice base, they should not be limited in formalistic issues but should bear the responsibility to instruct student's real knowledge so that they can experience the hardship of living in the society and establish correct employment values and career concept. Cultivate students' comprehensive abilities including innovative awareness and problem-solving ability, imagination and creativity. These are what the society can provide with students. Meanwhile, it should provide some fund support for students for startup funds so that our students can make attempts and development.

\section{School aspect}

Colleges should establish entrepreneurship education in accordance with national macro direction when responding to national polices, and combining entrepreneurship education and innovation education. Meanwhile, schools should formulate the development subjective and cultivation subjective of entrepreneurship education based on the economic development demands of the society so that students can establish their own career planning in the process of college study and make targeted study and set up basic theoretical framework, make deep research on college students' features and combine Chinese entrepreneurship education history to formulate specific implementation methods of entrepreneurship education. Chinese higher education is carried out in colleges and universities which should change previous old systems and keep up with the time for transition and guidance, especially for those application-oriented colleges which have great impact for cultivating professional talents. Regarding the cultivation of teachers, schools should provide professional trainings so as to instruct professional knowledge to students. Teaching resources will be the important bridge for our innovation and entrepreneurship education which plays a significant role. Regarding the course setting, schools should fully consider the integrality of subject and the degree that students can accept, research whether there are special subjects for entrepreneurship education, and what courses can match in the subject system. This requires for colleges to accumulate experience in the past during the process of practice so as to provide basis for the subsequent course 
setting, update education concept and continuously improve talent quality, explore advanced education and teaching methods. Thus, schools undertake larger responsibilities and missions.

\section{Student aspect}

Students should make efforts while responding the national and school policies. The core value of college entrepreneurship is to improve people's innovation awareness, entrepreneurship spirit and creativity, and cultivate innovative talents. Our students should fully improve themselves, establish correct employment values and job-choosing view, and fully arrange their time at campus and learn knowledge, enrich themselves, and improve their comprehensive quality and skills so as to prepare for the future stepping into the society. Students should also establish their own entrepreneurship education system, cultivate their innovation and entrepreneurship ability and perfect their personalities through mutual communication with classmates. Schools will also formulate related evaluation and rewards and punishment system to make relevant assessment on students. The standard of the evaluation is mainly for students themselves rather than the comparison between students. Students should modestly accept teachers' instructive suggestions so as to improve their defects and reduce difficulties in the future career development and entrepreneurship to fulfill their dreams and their values.

\section{Conclusion}

This article mainly discusses some problems during the process of college innovation and entrepreneurship education talent cultivation system construction under new situation and efforts all social sectors should make. The practice carried out in colleges will be the basic experience of the overall planning and cultivation of entrepreneurship education and it has significant impact. Entrepreneurship education itself is a tough and complicated project requiring us to spend time researching. In the process, there will be various problems waiting us to solve patiently. The country, society, schools, and ourselves, should make efforts to jointly respond to the appealing of innovative national strategy which has vast potential for future development.

\section{Reference}

[1] Wang Ge, Liu Qiaofei. A new education concept in colleges and universities---discussion of "Report on Chinese college innovation and entrepreneurship education development", China Higher Education Research; 9th period, 2009.

[2] Li Shujuan. Analysis on the current situation and influencing factors of college students' entrepreneurial practice-investigation and analysis on student start-up enterprises in Wuxi Wuxi institute of Commerce, Chinese University Technology Transfer; 12th period, 2014.

[3] Shi Guanqun, Liu Linqing, Chen Xiaoxia. Entrepreneurship network construction of innovation and entrepreneurship education and innovative college-take Stanford University as example, Studies In Foreign Education; 6th period, 2009.

[4] Li Mingjian. Personality characteristics and cultivation of innovative and entrepreneurial talents, Chinese University Technology Transfer; 8th period, 2014.

[5] Ma Nan, Chen Xinhao, Bai Yun. Construct college innovation experimental system and comprehensively cultivate innovative and entrepreneurial talents, Pioneering with Science \& Technology Monthly; 3rd period, 2014. 